\title{
Role of Pippalimulyadi Vati in stress induced Anidra (Insomnia)
}

\section{Research article}

\begin{tabular}{c}
\hline Vinod D. Patange ${ }^{\mathbf{1}^{*}, \text { Prakash Chavan }^{2} \text {, Vilasrao Jagatap }}{ }^{3}$ \\
1. Asst.Professor, Dept. of Dravyaguna, \\
2. Professor and HOD Dept of Kayachikitsa, \\
3. Professor and HOD Dept of Dravyaguna, \\
S C Mutha Aryangla Vaidyak Mahavidyalaya, I T I Road, Gendamal, Satara \\
\hline
\end{tabular}

\begin{abstract}
Aahara (food), Nidra (Sleep) and Bramhacharya are described to be the Trayopasthambas (Three supportive pillars). Hence forth, Sleep is one of the essential factors to lead a healthy life. It has been rightly stated by Acharya Charaka that happiness \& misery, proper \& improper growth, good strength \& weakness, potency \& sterility, knowledge \& ignorance and life \& death of an individual depend on proper and improper sleep. In the present study an effort is made to evaluate the efficacy of an herbal compound drug (Pippalimulyadi vati) in Anidra (insomnia) due to mentally stress. After completion of clinical trial it was observed that there was considerable improvement in the feeling of well being, physical and mental fitness in all the patients.
\end{abstract}

Keywords: Anidra, insomnia, Pippalimulyadi vati, stress

\section{Introduction}

Tridoshas i.e. Vata, Pitta and Kapha are described as Tristhuna (Three main pillars) of Ayurveda- the science of life. Similarly Aahara (food), Nidra (Sleep) and Bramhacharya are described to be the Trayopasthambas (Three supportive pillars). Hence forth, Sleep is one of the essential factors to lead a healthy life. It has been rightly stated by Acharya Charaka that happiness \& misery, proper \& improper growth, good strength \& weakness, potency \& sterility,

*Corresponding Author:

Vinod Patange,

Asst.Professor, Dept. of Dravyaguna,

$S \quad C$ Mutha Aryangla Vaidyak Mahavidyalaya,

I T I Road, Gendamal, Satara

Email id- vinodpatange@ rediffmail.com

Ph. no- 09028067171 knowledge \& ignorance and life \& death of an individual depend on proper and improper sleep(1). Insomnia (inadequate quality and quantity of sleep) may be a symptom of stressful lifestyle, depressive illness, anxiety disorders, any psychiatric conditions or any other pathological conditions. Whatever may be the cause of insomnia it needs immediate attention in present day lifestyle. It is affecting nearly $1 / 3^{\text {rd }}$ of population (especially youth) in western developed countries and the incidences are increasing day by day in the developing countries like India, Nepal, Sri Lanka, Bangladesh etc. If insomnia is left untreated, it may reduce mental capacity of an individual, reduce efficacy, increase the chances of various types of accident and ultimately it may drag the individual towards several severe psychosomatic disorders (2). 


\section{Need of the study}

In the present day different types of tranquilizers are used for the management of insomnia. Even though initially the tranquilizers give considerable relief in insomnia but continuous and long term use may induce various toxic effects including drug dependency. In such a scenario there is an immediate need for the efficient management of insomnia in a natural way with good counseling, usage of herbal medicines, following the proper life style and eradicating the problems. Need has always been felt to develop certain Ayurvedic treatment modalities for the management of Anidra (Insomnia) which could be safe, effective, readily available, cost effective without any side effects. In comparison to the therapeutic procedures of different systems of medicine, Ayurveda has a potent approach towards the treatment of Anidra. With these backgrounds an effort is made to evaluate the efficacy of an herbal compound drug (Pippalimulyadi vati) in Anidra (insomnia) due to mentally stress. This study was conducted in the University Department Cell (UDC), MUHS, Nashik \& Dr. M. N. Agashe Charitable Trust and Maternity Home (Aryangla Hospital), Satara.

\section{Aims and objectives \\ The present research trial was undertaken with the following main objectives- \\ 1. Conceptual and clinical studies on Anidra w.s.r. to insomnia and its management with time tested Ayurvedic principles.}

2. To evaluate the role of Pippalimulyadi yoga in mentally depressed Anidra

\section{Material \& Methods \\ Selection of the Drug}

Taking the symptoms and the Samprapti of Anidra into consideration, a proposed compound drug formulation naming "Pippalimulyadi Yog" was selected. This yoga contains Pippalimula, Ashwagandhamula, Jatamansimula. The Dravya Pippalimula acts as Nidrakar \& having vatanulomak property,
Ashwagandhamula is vatashamak and nidrajanan, Jatamansi is Manasdoshahar and nidrakar(3).

\section{Method of Preparation of Pippalimulyadi yoga}

The drugs Pippalimula, Ashwagandha \& Jatamansi are procured and standardized at Pharmacognosy department of Gourishankar Pharmacy College, Satara. They are then made into powder individually and then equal quantities of the powder of the three drugs and mixed well. Then the combined powder is made into tablets of $500 \mathrm{mg}$ each at Ayurvediya Arkashala Pharmacy.

\section{Dosage and Anupan}

Dose of Pippalimulyadi yoga tablet was 2 tabs (each of $500 \mathrm{mg}$ ) at the bed time with lukewarm water

\section{Selection of Cases}

In the present study a population of 20 clinically diagnosed patients of Anidra, due to insomnia, are selected from O.P.D. / I.P.D. unit of Dr. M.N.Agashe Charitable trust and Maternity Home, Satara. A regular record of the assessment of all patients was maintained according to format prepared for the purpose.

\section{Inclusive criteria}

1. Individuals between the age group of 16 to 80 years of both sexes having insomnia of minimum one month duration were selected randomly for the study.

2. Patients of Insomnia with mild hypertension, depression and anxiety disorders without any complications of any other diseases were included for the present study.

\section{Exclusive criteria}

1. Patients below $16 \mathrm{yrs}$ and above $80 \mathrm{yrs}$ of age are excluded.

2. Patients with major psychiatric illness like schizophrenia, depressive psychosis, epilepsy etc were not registered.

3. Patients with alcohol dependency or drug dependency were excluded from the study.

4. Patients having chronic illness like asthma, malignancies, liver cirrhosis, chronic renal failure, diabetes etc. were excluded. 
5. Patients with acute illness like Cardio Vascular Accident, Congestive Cardiac Failure, Myocardial Infarction, Chronic Obstructive Pulmonary Disorders, meningitis, and acute pain conditions and similar other disorders were excluded.

\section{Pre treatment observation}

All the patients have been studied along with the registration by noting down their demographic profile including their age, sex, address, occupation, education, socio economic status, marital status, life style, addictions, dietary habits etc. After preliminary registration, patients were subjected to detailed case history taking, physical, general and systemic examinations. In history and examination importance was given to mental status examination. During this all other relevant information like Ashtavidha Pariksha and Dashavidha Pariksha including assessment of Sharirika Prakriti and Manasika Prakriti (based on the features described in classical texts) etc. were noted.

\section{Criteria of Assessment}

Both subjective and clinical improvements were employed for assessment of the impact of the therapy. Subjective criteria of evaluation included the observations of both patients and assessment of the physician.

All the patients registered for the trial were specially asked for any changes or improvement in the time of sleep and the satisfaction after the sleep and their growing feeling of well being if any and either physical or mental fitness produced by the therapy during the trial.

The scoring of the subjective parameters is as follows:

Results:

Table 5: Showing the changes in the subjective parameters before and after the treatment and the statistical results:

\begin{tabular}{|l|l|l|l|l|l|l|ll|}
\hline Parameter & Mean & SE & SD & T value & p value & significance & \\
\cline { 2 - 7 } & $\begin{array}{l}\text { Before } \\
\text { treatment }\end{array}$ & $\begin{array}{l}\text { After } \\
\text { treatment }\end{array}$ & & & & & & \\
\hline Anidra & $\mathbf{3 . 6}$ & 0.9 & 0.11 & 0.5 & $\mathbf{2 0 . 4 8 7 2}$ & $\mathbf{> 0 . 0 0 0 1}$ & $\begin{array}{l}\text { Extremely statistically } \\
\text { significant }\end{array}$ & s.9. \\
\hline
\end{tabular}

\section{Discussion}

Nidra is one of the upasthambas mentioned in Ayurveda. It is one of the

\begin{tabular}{|l|l|l|}
\hline Satisfactory sleep with no dizziness & $:$ & 0 \\
\hline Satisfactory sleep but with dizziness & $:$ & 1 \\
\hline Unsatisfactory sleep & $:$ & 2 \\
\hline Disturbed sleep & $:$ & 3 \\
\hline Insomnia & $:$ & 4 \\
\hline
\end{tabular}

Observations:

Table 1: Showing the Gender wise distribution of the patients.

\begin{tabular}{|l|l|l|}
\hline Gender & Number & Percentage \\
\hline Male & 14 & 70 \\
\hline Female & 06 & 30 \\
\hline
\end{tabular}

Table 2: Showing the Age wise distribution of the patients

\begin{tabular}{|l|l|l|}
\hline Age & Number & Percentage \\
\hline $30-45$ & 09 & 45 \\
\hline $45-60$ & 09 & 45 \\
\hline $60-80$ & 02 & 10 \\
\hline
\end{tabular}

Table 3: Showing the Economic status wise distribution of the patients

\begin{tabular}{|l|l|l|}
\hline $\begin{array}{l}\text { Economic } \\
\text { status }\end{array}$ & Number & Percentage \\
\hline High & 04 & 20 \\
\hline Medium & 11 & 55 \\
\hline Low & 02 & 10 \\
\hline
\end{tabular}

Table 4: Showing the Marital Status wise distribution of the patients

\begin{tabular}{|l|l|l|}
\hline $\begin{array}{l}\text { Marital } \\
\text { status }\end{array}$ & Number & Percentage \\
\hline Married & 17 & 85 \\
\hline $\begin{array}{l}\text { Married but } \\
\text { without } \\
\text { spouse }\end{array}$ & 03 & 15 \\
\hline Unmarried & 00 & 00 \\
\hline
\end{tabular}


death. Anidra (Insomnia) has become a major problem with the increasing modernization and competitive lifestyle. This is because of the mental stress developed by the competitive atmosphere. So it is important to have a good drug which can prove to be efficacious in the treatment of Anidra.

The clinical study of 20 patients carried out in the present series revealed that majority of these cases were of age between 31-45 years and 45-60 years. This incidence shows that the complaints of insomnia rise as the age advances. In the trial urban people of middle class were found more affected and there was slight dominance of patients of male sex. It may be due to work stress and struggle for better life.

After completion of clinical trial it was observed that there was considerable improvement in the feeling of well being, physical and mental fitness in all the patients.

Taking Samprapti of Anidra into consideration, a compound drug formulation has been selected. The herbal drugs selected for preparation of the tablet were Pippalimula(4), Ashwagandha(5), Jatamansi(6). The drugs selected for the study mainly have Tikta, Kashaya Rasa, Laghu Guna, Ushna Virya (except Jatamamsi), Katu Vipaka (except Ashwagandha-Madhura Vipaka) and Kaphavatahara properties. All the selected drugs have Nadibalya, Mastishka Shamaka, Nidrajanaka and VatAhara properties. The drugs also act by Prabhava like Jatamansi is Bhutaghna i.e. Manasa Doshahara Prabhava.

Due to the above mentioned properties this combination showed significant therapeutic results.

\section{Conclusion:}

From the above study it can be concluded that the Pippalimuladi yoga is useful in the treatment of anidra in uncomplicated cases and it can prove a safe remedy without any side effects.

\section{Acknowledgement}

1. U D C, MUHS,Nashik

2. Dr.Prakash Chavan,Principal,S C Mutha Aryangla Vaidyak Mahavidyalaya,Satara.

3. Dr.M.N.Agashe Rugnalaya and Charitable Hospital,satara.

References:

1. Anonymous, Charaka Samhita e-book, New Delhi, CCRAS, 2010

2. www.emedicinehealth.com/insomnia/ article em.htm dt 25-07-2012 Time 11AM IST

3. Srikantha Murthy, Bhavaprakasha of Bhavamishra, Vol -I, Varanasi, Chowkhambha Krishnadas Academy, 2004, p.166

4. Ibid, p.168

5. Ibid, p. 220

6. Ibid, p. 257 